\title{
Lack of polymorphism of the agouti signaling protein (ASIP) gene among four different brown hare (Lepus europaeus Pallas 1778) populations
}

\author{
Noémi Soós - Szilvia Kusza \\ University of Debrecen Faculty of Agricultural and Food Sciences and Environmental Management, \\ Institute of Animal Science, Debrecen, Hungary \\ soos.noemi@agr.unideb.hu
}

\section{SUMMARY}

The brown hare (Lepus europaeus Pallas 1778) is a common palearctic and a popular game species therefore it has been an obvious subject for population genetic studies since the second part of the $20^{\text {th }}$ century. Among the several mitochondrial DNA studies some have been carried out concerning nuclear genes as well. The agouti signaling protein gene (ASIP) is involved in regulating the synthesis of eumelanin and pheomelanin in melanocytes of mammals. Though many studies focused on it in relation with several mammalian species, minimal information is available on this topic concerning the brown hare.

Here we present a short communication concerning the agouti signaling protein (ASIP) gene in four different country's L. europaeus populations, namely Lithuania, Hungary, Serbia and Georgia. $N=45$ tissue samples have been investigated from overall 17 sampling sites of the different countries. There has not been found any polymorphism among the sequences. In an alignment with other Leporid species 'partial ASIP sequences downloaded from ENA we have found that based on a 178 base pairs long DNA sequence the haplotype of our samples contains three other Lepus species as well. This is concordant with the findings of a previous study focusing predominantly on the European rabbit (Oryctolagus cuniculus Linnaeus 1758) and the several mutations of its ASIP gene.

Keywords: ASIP, colour regulating genes, Lepus europaeus, diversity, phylogeography

ÖSSZEFOGLALÁS

A mezei nyúl (Lepus europaeus Pallas 1778) egy igen elterjedt és népszerü, eredetileg palearktikus apróvad faj, amelynek populációi Európa szinte minden országában jelen vannak, ezáltal kézenfekvő alanyává vált különbözö populációgenetikai, filográfiai kutatásoknak a 20. század második felétöl. Számos mitokondriális DNS markerekre fókuszáló vizsgálatot végeztek különbözö állományain, s ezek mellett néhány tanulmány foglalkozott különbözö kromoszómális génjeivel is. Az aguti jelzőfehérje (ASIP) génje szerepet játszik az emlősök melanocitáiban az eumelanin és feomelanin festékanyagok termelödése szabályozásában. Bár sok diverzitáskutatást végeztek különbözö emlösfajokban a génnel kapcsolatban, a mezei nyúlról csekély információ áll rendelkezésünkre ezen a téren.

E rövid tanulmányban a faj négy különbözö országban (Litvánia, Magyarország, Szerbia és Grúzia) élö populációiból származó egyedek ASIP szekvenciáival kapcsolatos eredményünket tesszük közzé. 45 egyed szövetmintáit gyüjtöttük be összesen 17 mintavételi helyröl. Ezek feldolgozása után megállapítottuk, hogy a nagy földrajzi távolságok ellenére az adott génszakaszon nincs polimorfizmus az egyedek között. További Lepus fajok ASIP szekvenciáit az ENA oldalról letöltve azt találtuk, hogy egy rövid, 178 bázispáros illesztés alapján a mintáink génváltozata megegyezik három másik faj adott szakaszának szekvenciájával is. Ez összhangban van egy korábban a témában megjelent, de elsösorban az üregi nyúlra (Oryctolagus cuniculus Linnaeus 1758) fókuszáló kutatás eredményeivel.

Kulcsszavak: ASIP, szín szabályozó gének, Lepus europaeus, diverzitás, filogeográfia

\section{INTRODUCTION}

Colour of mammals and of wild animals in general is a primarily important factor regarding fitness. The presence or absence of the "proper" colour characteristic of a certain species can affect seriously the reproductive success and the adaptation to the environment. It plays important role in protection against the negative effects of solar radiation, in camouflage or even communication. Therefore a broad spectrum of colour traits had evolved that led to major differences among and in some cases even within species (Hofreiter and Schöneberg, 2010). This makes colour determining genes useful subjects for analysing genetic and phenotypic diversity and phylogeography of animal species.

The colour of mammalian skin and hair is predominantly determined by the secretion of two melanin types, the eumelanin and the pheomelanin (Simon et al., 2009) both of which are produced by the melanocyte cell type (Hearing and Tsakamoto, 1991). The production of these melanin molecules depends on the ligands connecting to the melanocortin 1 receptor $(\mathrm{MC} 1 \mathrm{R})$ on the plasma membrane of the melanocytes. Binding of the $\alpha$-MSH peptide (melanocyte-stimulating hormone) which is coded on the POMC gene (pro-opiomelanocortin) (Hofreiter and Schöneberg, 2010) results in secreting the brown or black eumelanin by the cell. The ASIP however acts as competitor and prevents the binding of $\alpha-\mathrm{MSH}$ to the MC1R eventuating the production of the red coloured pheomelanin (Gantz and Fong, 2003).

Both the Agouti locus, encoding the ASIP and the Extension locus, encoding the MC1R have been subject for several genetic and phylogenetic studies regarding several wild and domestic mammalian (e.g. mice Nachman et al., 2003; Hoekstra et al., 2006; fox - Våge et al., 1997; primates - Mundy and Kelly, 2003; sheep - Fontanesi et al., 2011; goats - Fontanesi et al., 2009) and other vertebrate species (fish - Selz et al., 2007; birds - Mundy, 2005). Concerning Lagomorphs there is very few information on the topic. Only a few studies have been taken place in connection with the colour regulating genes in this order (Fontanesi et al., 2006, 
2008, 2010; Koutsogiannouli et al., 2012; Nunome et al., 2014.) therefore it will take a lot of investigation to collect all the data needed to carry out phylogenetic studies.

During a long-term phylogenetic research based on both mitochondrial and nuclear markers we focus on the European brown hare. Although it is a well-studied species throughout the European continent there is very little known about its ASIP and MC1R encoding genes. We have a lot of information available on its diversity and phylogeography based on mitochondrial DNA markers (Djan et al., 2006; Stamatis et al., 2009; Mamuris et al., 2010) that show different degrees of genetic distance among and within brown hare populations of Europe. Our intention is to add to the knowledge on the species' diversity based on the abovementioned nuclear markers especially in Central- and EasternEurope.

\section{MATERIAL AND METHODS}

\section{Sample collection and preparation}

Forty-five individuals' tissue samples (liver or muscle or hairy skin) were used in this study collected from 17 sampling locations of four different countries [Lithuania - Marjampolè $(\mathrm{N}=5)$, Rykantai $(\mathrm{N}=2)$; Serbia - Novo Milosevo $(\mathrm{N}=2)$, Backa Palanka $(\mathrm{N}=1)$, Backa Topola $(\mathrm{N}=3)$, Bajina Basta $(\mathrm{N}=2)$, Voganj $(\mathrm{N}=3)$, Plandiste $(\mathrm{N}=1)$, Sonta $(\mathrm{N}=3)$, Krnjesevci $(\mathrm{N}=3)$, Nis $(\mathrm{N}=3)$, Ivanjica $(\mathrm{N}=2)$; Hungary - Túrkeve $(\mathrm{N}=4)$, Dormánd $(\mathrm{N}=4)$, Mezőnagymihály $(\mathrm{N}=2)$ and Georgia Kojori $(\mathrm{N}=2)$, Paravani Lake $(\mathrm{N}=1)$, Bakuriani $(\mathrm{N}=2)$ ] (Figure 1). The sampling periods were during the hunting seasons from 2007 until 2015.
Total genomic DNA was isolated from the tissue samples using either the E.Z.N.A. ${ }^{\circledR}$ Tissue DNA Kit (Omega Bio-Tek) or the High Pure PCR Template Preparation Kit (Roche). A DNA strand of 396 base pairs has been amplified with the primers (forward: 5'-CAGGAAGGCACATCCTCTTT-3'; reverse: 5'-TTCCCAAACCAAAGAAGTCAA-3') published by Fontanesi et al. (2008). The polymerase chain reactions were carried out in a $25 \mu \mathrm{L}$ reaction volume under the following thermal conditions with 35 reaction cycles: initial denaturation, $94^{\circ} \mathrm{C}, 5 \mathrm{~min}$; denaturation, $94{ }^{\circ} \mathrm{C}, 1 \mathrm{~min}$; annealing, $60{ }^{\circ} \mathrm{C}, 1 \mathrm{~min}$; elongation, $72{ }^{\circ} \mathrm{C}, 1 \mathrm{~min}$; final elongation, $72{ }^{\circ} \mathrm{C}, 5 \mathrm{~min}$. A DNA Engine Peltier (PTC-200) thermal cycler (Bio-Rad) was used to perform the reactions. For the visualization of the electrophoretic pattern ethidium bromide has been used in 2\% agarose gel. Purification and sequencing of the PCR product have been carried out by Macrogen Europe as a service.

\section{Sequence analysis}

Sequences have been aligned with CodonCode Aligner v.6.0.2 (CodonCode Corporation, www. codoncode.com) and ClustalOmega at EMBL-EBI (Goujon et al., 2010) and re-checked by eye. We have got a $330 \mathrm{bp}$ long alignment to proceed with.

Into our study there have been included further sequences of different species' ASIP genes (exon 2) that have been downloaded from the European Nucleotide Archive (Table 1). DnaSP 5.10 software (Rozas et al., 2003; Librado and Rozas, 2009) was used to determine the number of haplotypes while MEGA 6.06 (Tamura et al., 2013) to build a phylogenetic tree.

Figure 1: Map of the countries of $L$. europaeus populations included in this study

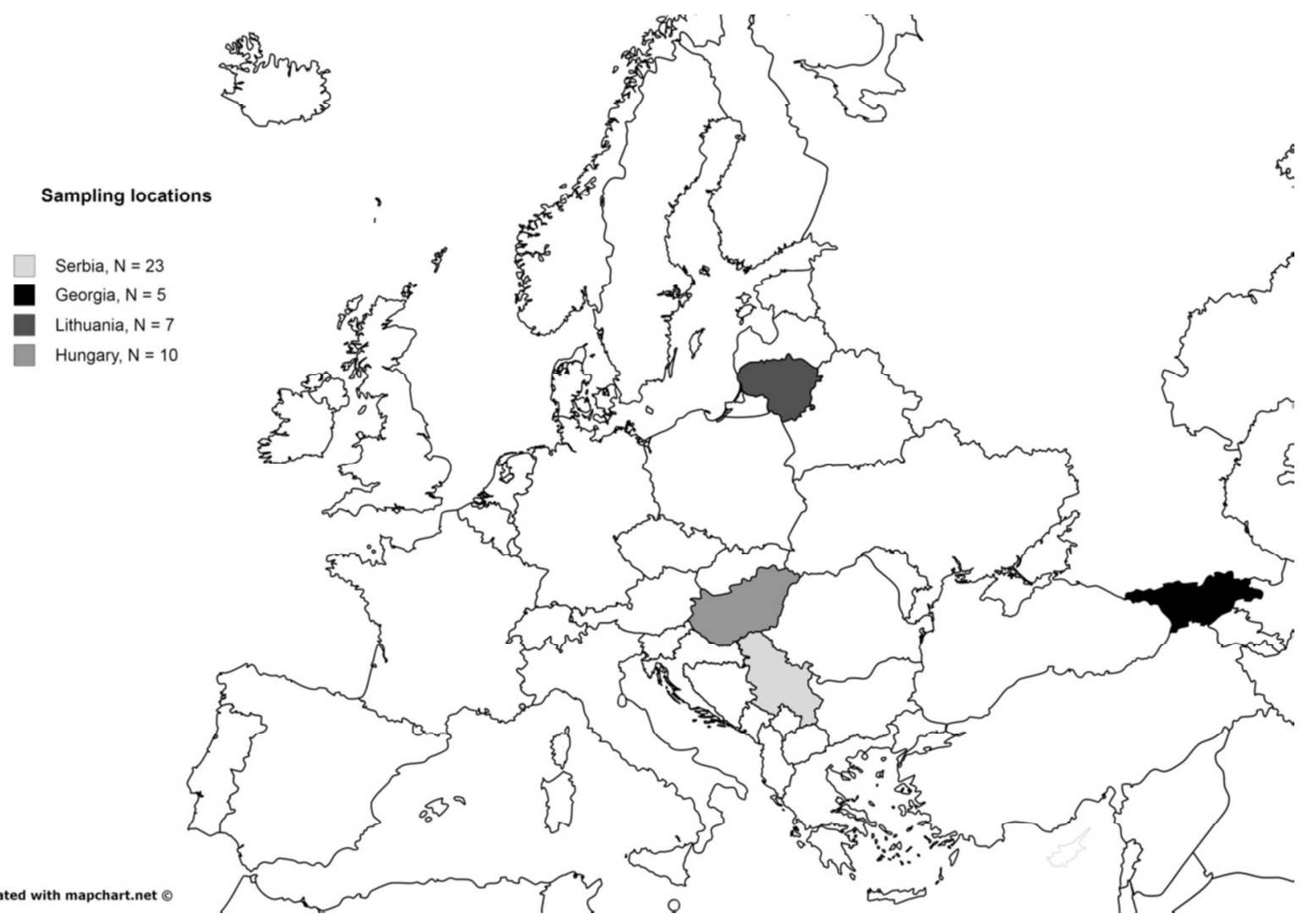


Table 1.

Partial sequences of Leporid species' ASIP genes downloaded from ENA

\begin{tabular}{lc}
\hline \multicolumn{1}{c}{ Species } & Accession No. \\
\hline L. europaeus & FN547142.1 \\
L. europaeus & AM909654.1 \\
L. timidus & CBC05685.1 \\
L. othus & CBC05689.1 \\
L. americanus & CBC05687.1 \\
L. brachyurus & AB595239.1 \\
O. cuniculus & CAO83027.1 \\
\hline
\end{tabular}

Note: all sequences except for the one of $L$. brachyurus have been published by Fontanesi et al. (2008). The L. brachyurus sequence was published by Nunome et al. (2014).

\section{RESULTS}

During the sequence analysis we have found a total identity among all of our 45 brown hare ASIP sequences, we could not describe any polymorphisms at all.

After an alignment with all the other species' sequences (178 base pairs) there have been revealed three haplotypes with both DnaSP and MEGA. The first one contained all of our samples along with the downloaded L. timidus, L. othus, L. americanus and L. europaeus sequences. Both the L. brachyurus and O. cuniculus sequences represented separate haplotypes. For tree construction the Kimura 2 - parameter method + G (Kimura 1980) has been chosen according to the suggestion of MEGA Modeltest. The tree also shows the abovementioned similarity among our samples (Figure 2).

Figure 2: Maximum likelihood tree of our 45 samples and the ENA sequences based on $\mathbf{K 2}+\mathbf{G}$ model

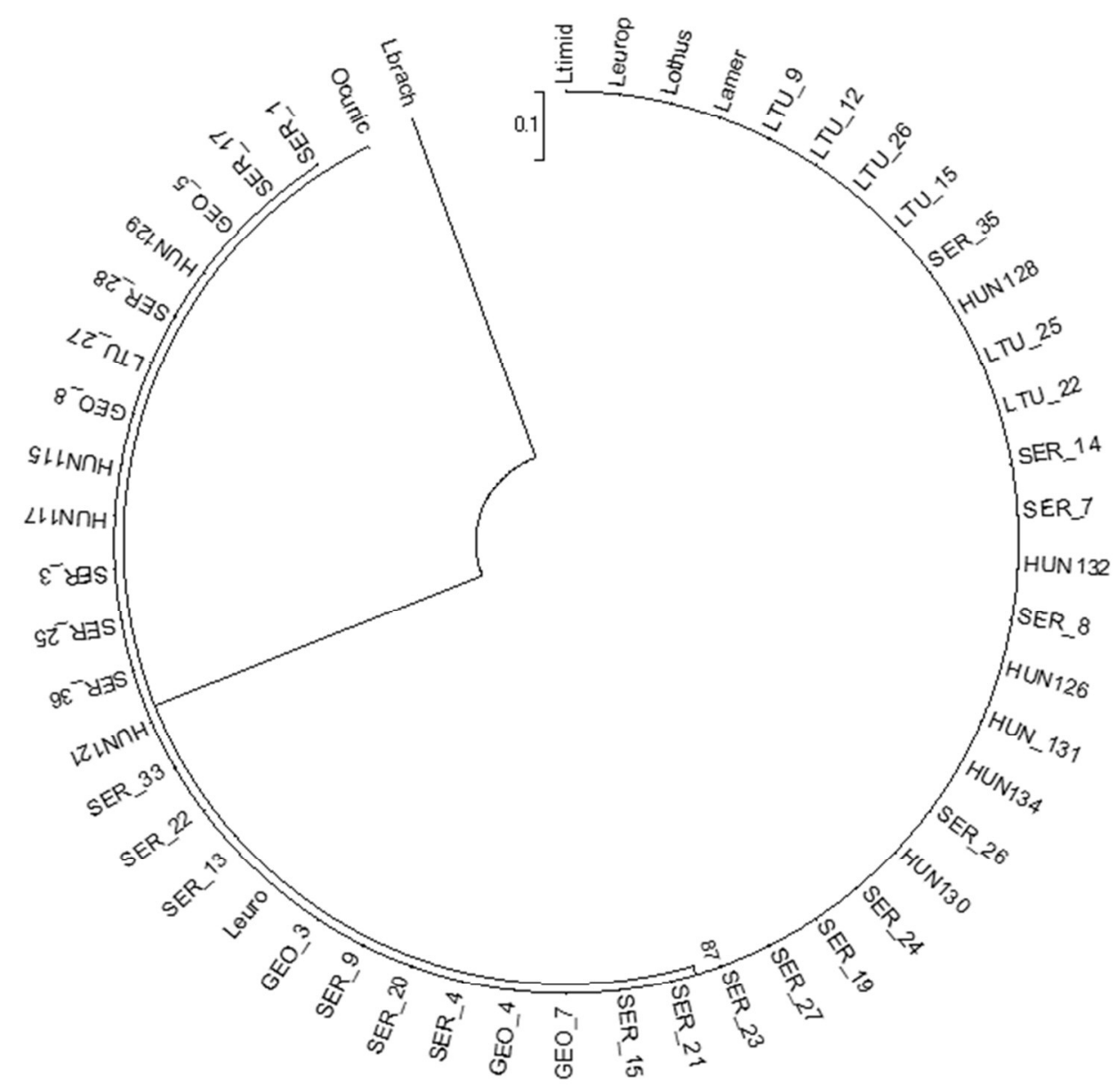

\section{DISCUSSION}

Though several studies have been carried out regarding the phylogenetics of the L. europaeus that have provided a great amount of information on its present population genetic status and phylogeography, our knowledge is still shallow on the species' genetic diversity based on nuclear markers especially on colour regulating genes. It can be declared that aside from two Lepus species and the European rabbit we know almost nothing about these markers in Leporidae.
In relation to the European rabbit Fontanesi et al. $(2008,2010)$ have described a certain degree of diversity of colour determining genes within the species. Both on the Agouti and Extension loci multiple alleles have been described. 31 different rabbit breeds have been investigated concerning the ASIP gene, and there have been 19 polymorphisms described, of which one turned out to be functionally significant. The 19 polymorphisms have been organized into 5 haplotypes. These sequences have been compared to nine other Leporid species' ASIP genes and there has been described that four Lepus 
species' partial ASIP sequences were identical to each other. These were the L. europaeus, the L. timidus, the $L$. americanus and one of two haplotypes of the $L$. othus. This is in congruence with our results also.

Another study by Nunome et al. (2014) has described 12 different alleles on the Agouti locus in the $L$. brachyurus populations of Japan, and they suggest a connection with the seasonal coat colour changing. Koutsogiannouli et al. (2012) reported two MC1R alleles (Leu1, Leu2). Leu1 was present in Turkish individuals and in the rest from all over Europe while Israeli brown hares carried the Leu2 allele. Israeli hares differed from the rest in fur colour as well.

All three studies that revealed polymorphism on the Agouti and Extension loci focused on populations whose fur colour is not necessarily uniform. There are L. brachyurus populations in Japan that change the fur colour seasonally and ones that do not as well. The L. eurpaeus individuals that differed in their MC1R alleles differed in fur colour also. And at last O. cuniculus breeds are certainly artificially selected thus differ from each other explicitly in many traits among hair colour. Since the L. europaeus regarding its fur colour is a quite uniform species, at least on the European continent, with no seasonal colour change at all it can be declared that the identity of all of our samples can be expected in spite of the high diversity values described previously in mtDNA based studies (e.g. Mamuris et al., 2001; Stamatis et al. 2009). Mutations of functional nuclear genes regulating such important traits as the colouration can of course be beneficial. This is the most important driving force of evolution (Carlin, 2011). Although the unsuccessful adaptation to the environment and thus easily becoming a prey and the disadvantage during mating are expressly risky for wild living species therefore these mutations can be very harmful as well to the evolution of those which can explain the lack of polymorphism of these genes.

\section{ACKNOWLEDGEMENTS}

This project was supported by the János Bolyai Research Scholarship of the Hungarian Academy of Sciences. The authors would like to thank Dr. Mihajla Djan, Dr. Natia Kopaliani, Dr. Algimantas Paulauskas, Dr. László Szendrei and Péter Farkas for providing us with the samples used is this study.

\section{REFERENCES}

Carlin, J. L. (2011): Mutations Are the Raw Materials of Evolution. Nature Education Knowledge. 3. 10: 10.

Djan, M.-Obreht, D.-Vapa, L. (2006): Polymorphism of mtDNA regions in brown hare (Lepus europaeus) populations from Vojvodina (Serbia and Montenegro). European Journal of Wildlife Research. 52: 288-291.

Fontanesi, L.-Tazzoli, M.-Beretti, F.-Russo, V. (2006): Mutations in the melanocortin 1 receptor (MC1R) gene are associated with coat colours in the domestic rabbit (Oryctolagus cuniculus). Animal Genetics. 37: 489-493.

Fontanesi, L.-Oulmouden, A.-Tazzoli, M.-Allain, D.-Deretz, S.Robinson, T. J.-Pecchioli, E.-Cook, J.-Russo, V. (2008): Investigation of coat colour affecting genes in several european rabbit breeds and other leporid species. Presented at 9. World Rabbit Congress. Vérone. Italy. 67-71.

Fontanesi, L.-Beretti, F.-Riggio, V.-Gómez González, E.-Dall'Olio, S.-Davoli, R.-Russo, V.-Portolano, B. (2009): Copy Number Variation and Missense Mutations of the Agouti Signaling Protein (ASIP) Gene in Goat Breeds with Different Coat Colors. Cytogenetic and Genome Research. 126: 333-347.

Fontanesi, L.-Forestier, L.-Allain, D.-Scotti, E.-Beretti, F.-DeretzPicoulet, S.-Pecchioli, E.-Vernesi, C.-Robinson, T. J.-Malaney, J. L.-Russo, V.-Oulmouden, A. (2010): Characterization of the rabbit agouti signaling protein (ASIP) gene: Transcripts and phylogenetic analyses and identification of the causative mutation of the nonagouti black coat colour. Genomics. 95: 166-175.

Fontanesi, L.-Dall'Olio, S.-Beretti, F.-Portolano, B.-Russo, V. (2011): Coat colours in the Massese sheep breed are associated with mutations in the agouti signalling protein (ASIP) and melanocortin 1 receptor (MC1R) genes. Animal. 5. 1: 8-17.

Gantz, I.-Fong,T. M. (2003): The melanocortin system. Am. J. Physiol. 284: E468-E474.
Goujon, M.-McWilliam, H.-Li, W.-Valentin, F.-Squizzato, S.Paern, J.-Lopez, R. (2010): A new bioinformatics analysis tools framework at EMBL-EBI. Nucleic Acids Research. 38. Suppl. W695-699.

Hearing, V. J.-Tsakamoto, K. (1991): Enzymatic control of pigmentation in mammals. The FASEB Journal. 5.14: 2902-2909.

Hoekstra, H. E.-Hirschmann, R. J.-Bundey, R. A.-Insel, P. A.Crossland, J. P. (2006): A single amino acid mutation contributes to adaptive beach mouse color pattern. Science. 313: 101-104.

Hofreiter, M.-Schöneberg, T. (2010): The genetic and evolutionary basis of colour variation in vertebrates. Cellular and Molecular Life Sciences. 67: 2591-2603.

Kimura, M. (1980): A simple method for estimating evolutionary rates of base substitutions through comparative studies of nucleotide sequences. Journal of Molecular Evolution. 16: 111-120.

Koutsogiannouli, E. A.-Moutou, K. A.-Stamatis, C.-Mamuris, Z (2012): Analysis of MC1R genetic variation in Lepus species in Mediterranean refugia. Mammalian Biology. 77. 6: 428-433.

Librado, P.-Rozas, J. (2009): DnaSP v5: A software for comprehensive analysis of DNA polymorphism data. Bioinformatics. 25: 1451-1452.

Mamuris, Z.-Sfougaris, A. I.-Stamatis C. (2001): Genetic structure of Greek brown hare (Lepus europaeus) populations as revealed by mtDNA RFLP-PCR analysis: Implications for conserving genetic diversity. Biological Conservation. 101. 2: 187-196.

Mamuris, Z.-Moutou, K. A.-Stamatis, C.-Sarafidou, Th.-Suchentrunk, F. (2010): Y DNA and mitochondrial lineages in European and Asian populations of the brown hare (Lepus europaeus). Mammalian Biology. 75: 233-242.

Mundy, N. I. (2005): A window on the genetics of evolution: MC1R and plumage colouration in birds. Proceedings of the Royal Society B: Biological Sciences. 272: 1633-1640. 
Mundy, N. I.-Kelly, J. (2003): Evolution of a pigmentation gene, the melanocortin-1 receptor, in primates. American Journal of Physical Anthropology. 121: 67-80.

Nachman, M. W.-Hoekstra, H. E.-D’Agostino, S. L. (2003): The genetic basis of adaptive melanism in pocket mice. Proceedings of the National Academy of Sciences. 100: 5268-5273.

Nunome, M.-Kinoshita, G.-Tomozawa, M.-Torii, H.-Matsuki, R.Yamada, F.-Matsuda, Y.-Suzuki, H. (2014): Lack of association between winter coat colour and genetic population structure in the Japanese hare, Lepus brachyurus (Lagomorpha: Leporidae). Biological Journal of the Linnean Society. 111: 761-776.

Rozas, J.-Sánchez-DelBarrio, J. C.-Messeguer, X.-Rozas, R. (2003): DnaSP, DNA polymorphism analyses by the coalescent and other methods. Bioinformatics. 19: 2496-2497.

Selz, Y.-Braasch, I.-Hoffmann, C.-Schmidt, C.-Schultheis, C.Schartl, M.-Volff, J. N. (2007): Evolution of melanocortin receptors in teleost fish: the melanocortin type 1 receptor. Gene. 401: 114-122.
Simon, J. D.-Peles, D.-Wakamatsu, K.-Ito, S. (2009): Current challenges in understanding melanogenesis: bridging chemistry, biological control, morphology and function. Pigment Cell \& Melanoma Research. 22: 563-579.

Stamatis, C.-Suchentrunk, F.-Moutou, K. A.-Giacometti, M.Haerer, G.-Djan, M.-Vapa, L.-Vukovic, M.-Tvrtković, N.Sert, H.-Alves, P. C.-Mamuris, Z. (2009): Phylogeography of the brown hare (Lepus europaeus) in Europe: a legacy of southeastern Mediterranean refugia? Journal of Biogeography. 36: 515-528.

Tamura, K.-Stecher, G.-Peterson, D.-Filipski, A.-Kumar, S. (2013): MEGA6: Molecular Evolutionary Genetics Analysis Version 6.0. Molecular Biology and Evolution. 30: 2725-2729.

Våge, D. I.-Lu, D. S.-Klungland, H.-Lien, S.-Adalsteinsson, S.Cone, R. D. (1997): A non-epistatic interaction of agouti and extension in the fox, Vulpes vulpes. Nature Genetics. 15: 311-315. 
